\title{
Germinal Cells in the Goldfish Retina That Produce Rod Photoreceptors
}

\author{
Pamela A. Raymond ${ }^{1}$ and Patricia K. Rivlin
}

\author{
Department of Anatomy and Cell Biology, The University of Michigan Medical School, Ann Arbor, Michigan $48109-0010$ \\ Received April 4, 1986; accepted in revised form February 12, 1987
}

\begin{abstract}
Dividing cells and their progeny in retinae of young goldfish were labeled with $\left[{ }^{3} \mathrm{H}\right]$ thymidine, and selected cells were reconstructed from serial sections processed for electron microscopic autoradiography. Our goals were to characterize the cells that were identified as rod precursors in previous light microscopic autoradiographical studies and to determine their origin and fate. (In fish the population of rods increases several-fold postembryonically by proliferation of rod precursor cells scattered across the retina.) Over 200 labeled cells taken from 11 retinas were examined, and 20 of these were reconstructed in their entirety. Some retinas were examined at short intervals ( 1 to $48 \mathrm{hr})$ after $\left[{ }^{3} \mathrm{H}\right]$ thymidine injection in order to study mitotically active cells, and others were examined after longer intervals (9 or 14 days) to discover the nature of the progeny of labeled dividing cells. Previous evidence from thymidine studies in larval goldfish suggested that proliferating cells destined to produce rods appear first in the inner nuclear layer and later in the outer nuclear layer, where they continue to divide and generate new rods (P. R. Johns, (1982) J. Neurosci. 2, 179). The present results provide morphological evidence in support of the suggestion that rod precursors migrate from inner to outer nuclear layer and, furthermore, show that the precursors are closely associated with, and perhaps guided by, the radial processes of Müller glial cells. Examination of EM autoradiographs of labeled cells at 9 and 14 days after a pulse label with thymidine confirms that the differentiated progeny of dividing precursor cells are exclusively rods. To our knowledge, rod precursors are the first example of a neuronal germinal cell in the vertebrate central nervous system that under normal conditions produces only one type of neuron. (c) 1987 Academic Press, Inc.
\end{abstract}

\section{INTRODUCTION}

The circumferential pattern of retinal growth in teleost fish and amphibians is well known (Easter, 1983). Postembryonic neurogenesis takes place in an annular germinal zone located at the junction between neural retina and iris epithelium. The germinal zone in the teleost retina was recognized over 30 years ago on the basis of its histological appearance and the presence of mitotic figures (Müller, 1952; Lyall, 1957). Later studies used $\left[{ }^{3} \mathrm{H}\right]$ thymidine autoradiography to label the new cells produced in the germinal zone (Straznicky and Gaze, 1971; Johns, ${ }^{2}$ 1977; Meyer, 1978), and cell counts were used to document the increase in numbers of retinal neurons with growth of the retina (Müller, 1952; Johns and Easter, 1977; Kock and Reuter, 1978; Kock, 1982; Negishi et al., 1985).

Recently, it was discovered that rods in the postembryonic teleost retina are produced by a scattered population of dividing cells located among the nuclei of mature rods in the outer nuclear layer, whereas other retinal neurons are produced only in the circumferential germinal zone (Sandy and Blaxter, 1980; Johns and Fernald, 1981; Johns, 1982; Munk and Jørgensen, 1983; Raymond, 1985a). Rod precursors can be labeled with

\footnotetext{
${ }^{1}$ To whom correspondence should be addressed.

${ }^{2}$ P. A. Raymond published previously under the name P. R. Johns.
}

$\left[{ }^{3} \mathrm{H}\right]$ thymidine and their progeny appear (by light microscopic criteria) to differentiate into rods (Johns and Fernald, 1981; Johns, 1982). Few if any rods appear to be produced by the circumferential germinal zone itself, since the most peripheral segment of retina adjacent to the germinal zone, and most recently produced by it, is rod-poor (Vilter, 1947; Müller, 1952; Johns, 1982). The terminal mitotic divisions that produce definitive rods, in larval retinae or in the newly added peripheral annulus of retinae in older fish, take place after the other postmitotic cells have been partitioned into their appropriate laminae and synaptogenesis has commenced (Johns, 1982; Branachek and BreMiller, 1984; Raymond, 1985a). Not only is the genesis of rods delayed in the teleost retina, but also it is unusually prolonged. The production of rods by mitotic precursor cells does not stop, even in adult fish, and new rods are continually inserted into the photoreceptor mosaic as the retina grows postembryonically (Blaxter and Jones, 1967; Blaxter and Staines, 1970; Locket, 1980; Johns and Fernald, 1981; Johns, 1982). As a consequence the total number of rods increases at a much faster rate than other retinal cells (Müller, 1952; Johns and Easter, 1977; Johns, 1982). For example, as goldfish grow from 5 to 20 $\mathrm{cm}$ standard length, the total number of cones increases by 5.5 -fold, from 250,000 to $1,400,000$; at the same time rods increase in number 10 -fold, from $1,500,000$ to 
15,000,000 (Johns and Easter, 1977). The relative increases in numbers of other retinal neurons (ganglion cells and interneurons) are similar to cones (Müller, 1952; Johns and Easter, 1977; Kock and Reuter, 1978; Kock, 1982).

Most previous studies have focused on histological characteristics of rod precursors such as their location and distribution, but little is known about their origin and nothing is known about their ultrastructural morphology, since all previous observations were made with light microscopy. These earlier descriptions were necessarily limited since in the light microscope the nuclei of precursors cannot be reliably distinguished from surrounding nuclei of mature rods, unless they are in mitosis or are labeled with $\left[{ }^{3} \mathrm{H}\right]$ thymidine (Sandy and Blaxter, 1980; Johns and Fernald, 1981; Johns, 1982; Munk and Jørgensen, 1983; Raymond, 1985a).

The present study is an attempt to examine with electron microscopy the relationship between rod precursors and rods. We identified rod precursors in serial sections and used computer graphics techniques to reconstruct them. We then used these reconstructions to trace their ontogenetic pathway. Our previous studies had suggested the following scheme: primitive neuroepithelial cells produce specialized rod precursors which then form postmitotic rods. Here we provide evidence that supports our earlier suggestion. Rod precursors apparently arise from mitotically active nests of undifferentiated cells located initially in the inner nuclear layer. These cells, still mitotically active, appear to migrate across the outer plexiform layer to the outer nuclear layer where they either continue to divide or give rise to rods. An unexpected finding was that the rod precursors are intimately associated with radial processes of Müller fibers as they move from the inner to the outer nuclear layer. Preliminary accounts of these results have appeared in two abstracts (Raymond and Rivlin, 1984, 1985).

\section{METHODS}

Goldfish were raised from eggs spawned in the laboratory. Adult fish in breeding condition purchased from Ozark Fisheries (Stoutland, MO) were maintained as described previously (Johns, 1982; Raymond, 1985b) so that embryos could be obtained throughout the year. The culturing of embryos and rearing of larval and juvenile fish were also described previously (Johns, 1982; Raymond, 1985b). Larval development in goldfish kept at $21^{\circ} \mathrm{C}$ lasts about 3 weeks (Kajishima, 1960). There are no obvious changes in the structure or growth of the retina associated with stages of larval development, however, and production and maturation of retinal neurons, including genesis and differentiation of rods, take place continuously throughout larval and juvenile life.

\section{Rationale for $\left[{ }^{3} H\right]$ Thymidine Labeling}

By varying the survival time following an injection of $\left[{ }^{3} \mathrm{H}\right]$ thymidine, one can study both proliferating cells and their progeny (Rogers, 1979). We have exploited this idea in studying the retina of young goldfish by selecting two ranges of survival times: less than $48 \mathrm{hr}$ or 9 to 14 days (Table 1). Cells labeled at $48 \mathrm{hr}$ or less are assumed to represent dividing cells; those labeled at 9 or 14 days after injection we assume have ceased dividing. These assumptions are bascd on the following reasoning. (1) Although we do not know the precise length of time that a single pulse of $\left[{ }^{3} \mathrm{H}\right]$ thymidine is available for incorporation in goldfish, by analogy with larval amphibians where it has been measured (Beach and Jacobson, 1979; Heathcote and Sargent, 1984), this interval is less than a few hours. Thus cells can incorporate $\left[{ }^{3} \mathrm{H}\right]$ thymidine only during a short interval after the injection. (2) The cell cycle of proliferating cells in the outer nuclear layer of juvenile goldfish retina has been estimated to be 20 hr (Johns, 1982), which means that the amount of label in cells that continue to proliferate is reduced by half roughly every day. (3) The maximum grain count (No. of silver grains overlying a nucleus) in our preparations was between 70 and 100 grains, so by 6 days, with continued proliferation, the grain count over proliferating cells would be reduced to background levels ( $\leqslant 3$ grains per nucleus). Therefore cells that retain label after 1 week must have ceased dividing earlier.

\section{$\left[{ }^{3} H\right]$ Thymidine Injections and Tissue Preparation}

Late larval/early juvenile fish, aged 20 to 51 days after hatching, were anesthetized in $0.02 \%$ tricaine methane sulfonate (Sigma). A micropipet with a tip diameter of about $30 \mu \mathrm{m}$ was used to inject approximately $1 \mu \mathrm{Ci}$ of $\left[{ }^{3} \mathrm{H}\right]$ thymidine (90 to $100 \mathrm{Ci} /$ mole, New England Nuclear) intraperitoneally as described previously (Johns, 1982). The fish ranged in size from 0.5 to $1.2 \mathrm{~cm}$ standard length. The oldest fish were not necessarily the largest, however, since growth rate varies markedly among individuals (Müller, 1952; Raymond, 1986). Variable growth rates are typical of teleost fish even when kept under rigorously controlled and presumably identical rearing conditions (Brown, 1957). One hour to 14 days after the thymidine injection the fish were killed by decapitation, and the heads were fixed in a mixture of ice-cold buffered aldehydes: 3 to $5 \%$ glutaraldehyde, 1 to $3 \%$ paraformaldehyde, $0.1 \%$ picric acid, $5 \%$ sucrose, $1 \mathrm{mM} \mathrm{CaCl}$ in $0.1 M$ phosphate buffer, $\mathrm{pH} 7.4$ (modified from Langford and Coggeshall, 1980, 1981). In most cases, a hole was made in the cornea with an insect pin to aid penetration of fixative to the retina. After $1 \mathrm{hr}$ in ice-cold fixative, one eye was removed and fixed separately and the other eye was left in the bisected head; fixation continued 
TABLE 1

LABELED CELLS IN THE INNER AND OUter NuClear LAYer

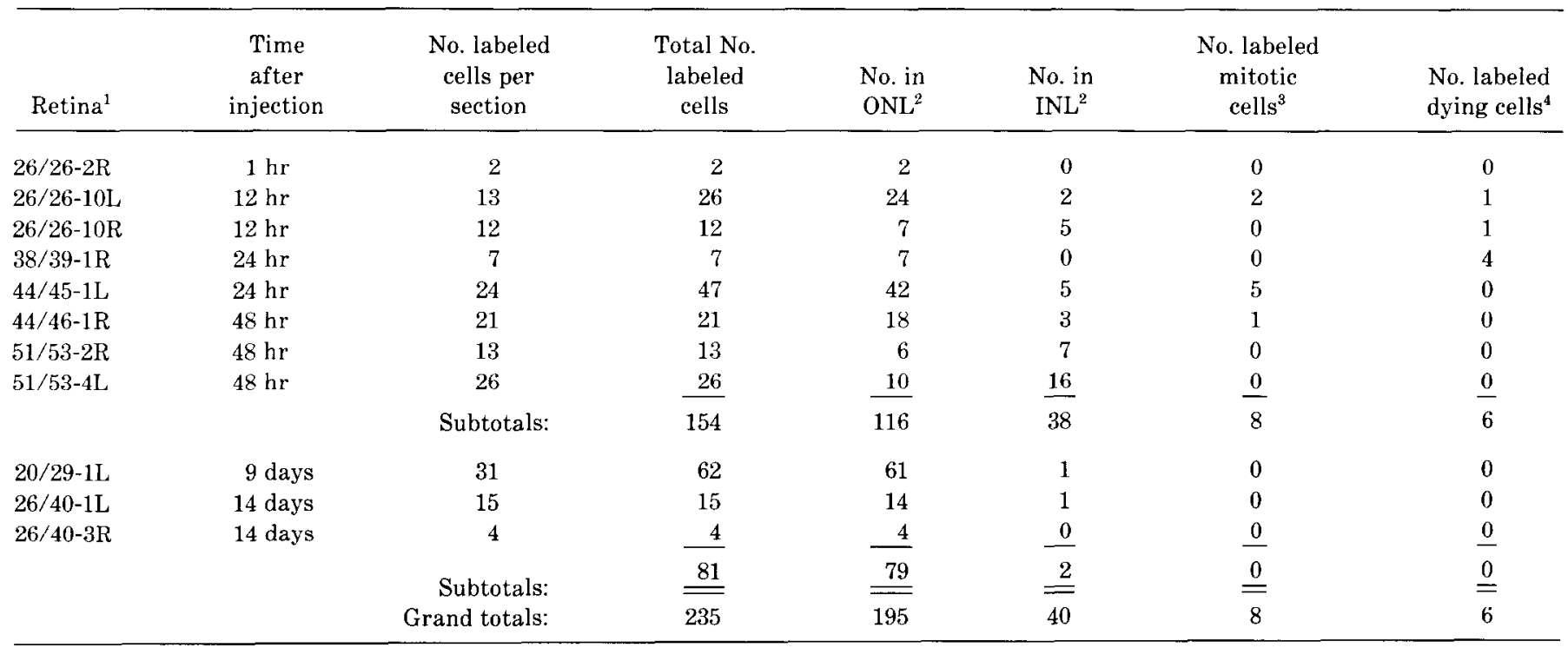

\footnotetext{
${ }^{1}$ Each entry is one retina. Fish are identified by a code: the first number indicates age (in days) at injection/the second number is age at sacrifice. The number following the dash identifies a specific fish, and the letters " $\mathrm{R}$ " or " $\mathrm{L}$ " signify right or left eye, respectively. One or two sections were analyzed from each retina.

${ }^{2}$ Those cells located entirely or partially in the outer plexiform layer were tallied with either the ONL or the INL counts, depending on which layer they were more closely associated with.

${ }^{3}$ All labeled mitotic cells were found in the ONL (excluding those in the CGZ). Additional unlabeled mitotic cells were seen in some retinae, in both the ONL and the INL.

${ }^{4}$ All labeled dead or dying cells were found in the ONL (excluding those in the CGZ). Additional unlabeled dying cells were seen in the ONL of many retinae. Labeled dying cells are not included in the counts of labeled cells (columns 3 to 6 ).
}

overnight at $4^{\circ} \mathrm{C}$. After being rinsed in cold $0.1 \mathrm{M}$ phosphate buffer with $5 \%$ sucrose, the tissues were postfixed in a mixture of $1 \%$ osmium tetroxide and $1.5 \%$ potassium ferricyanide in $0.1 M$ phosphate buffer, $\mathrm{pH} 7.4$ (Langford and Cogeshall, 1980,1981), or $2 \%$ osmium tetroxide in the same buffer for $1.5 \mathrm{hr}$ at room temperature. The osmium ferricyanide markedly enhances membrane contrast and, in the most favorable preparations, actually precipitates into extracellular spaces. This procedure was essential for the serial reconstructions of cells. Further details of our methods will be presented in another publication (Rivlin and Raymond, J. Neurosci. Meth., in press). In some cases, the tissue was stained en bloc with $1 \%$ uranyl acetate. All eyes were dehydrated in graded ethanols and embedded in Spurr's medium (Polysciences).

Blocks were carefully oriented so that the eyes were sectioned parallel to the dorsoventral meridian. For orientation, we used the scar that represents the site of closure of the embryonic choroid fissure and which is located on the ventral side of the iris. The block was faced until the section plane was near the center of the eye, at which point semithin $(0.5 \mu \mathrm{m})$ sections were mounted and prepared for light microscopic autoradiography using NTB2 emulsion (Kodak) and standard procedures (Rogers, 1979). Each section contained a complete transection of retina, from one margin to the other. Eleven well-fixed retinas containing abundant heavily labeled cells were selected for further processing with EM autoradiography.

\section{Electron Microscopic Autoradiography}

A modified flat substrate method (Salpeter and Bachmann, 1964; Davis et al., 1979) was used for the EM autoradiography. Briefly, short ribbons of silver sections were mounted onto slides (two to three ribbons per slide) that had been coated in $0.6 \%$ Parlodion and allowed to dry. Slides were then dipped in Ilford L4 emulsion heated to $50^{\circ} \mathrm{C}$ and diluted $1: 1$ with distilled water to which 2 drops of glycerol was added per $30 \mathrm{ml}$. Use of a semiautomatic dipping device (Rogers, 1979) grcatly facilitated consistent production of even monolayers of emulsion. After exposure times of 5 days to 2 weeks at $4^{\circ} \mathrm{C}$, the autoradiographs were developed in $\mathrm{D}$ 19 (Kodak). The Parlodion film with attached sections was stripped from the slide onto water, and a 1 by 2 $\mathrm{mm}$ single-hole copper slot grid was carefully lowered over each ribbon. After applying a Formvar film $(0.5 \%)$ the sections were stained with lead citrate and uranyl 
acetate and viewed with a Philips 400 electron microscope. In all, 235 thymidine-labeled rods or rod precursors were studied in EM autoradiographs (see Table 1). One or two selected sections were analyzed for each retina; the retina was scanned from one margin to the other, and all labeled cells were photographed. The volume sampled from each retina ranged from 7000 to 23,000 $\mu \mathrm{m}^{3}$; this represents 0.01 to $0.2 \%$ of the total retinal volume.

\section{Computer-Aided Serial Reconstruction}

Twenty thymidine-labeled and five unlabeled dividing precursor cells were completely reconstructed and six unlabeled Müller cells were partially reconstructed from serial sections. Three sets of serial sections, consisting of 188,253 , and 141 sections, respectively, derived from two retinas, were used in the reconstructions. At intervals of 25 sections, 2 or 3 sections were reserved and processed for EM autoradiography, and the remainder of the sections were prepared for conventional EM. Photographic mosaics were prepared from autoradiographic sections near the center of the serial set; labeled cells suitable for reconstruction and located in the central one-third of the retina were selected. Photographs at a final magnification of 8900 or $15,000 \times$ were made of each cell of interest on every fifth section, and the outer boundaries of the cells and their nuclei were traced onto acetate sheets. Prints were viewed under a dissecting microscope when necessary to more clearly distinguish cellular boundaries. When problems arose in identifying a given profile in successive photographs, the intervening sections were photographed and examined. Alignment of the transparencies was accomplished by superimposing as closely as possible the profiles traced on each sheet with the corresponding profiles on the next sheet in the series, using neighboring large distinctive cells and the boundaries of the retinal laminae as fiducial landmarks.

The tracings were digitized on a Summagraphics tablet linked to a Tektronix 4054 computer. Digitized images were processed with a computer graphics program, PLOTTER (developed by J. Kilgore, T. Connelly, F. Bookstein, and P. Raymond; proprietary software of the University of Michigan). Reconstructed cells were viewed on the Tektronix; hard copies were obtained with a CalComp or a Hewlett-Packard HP7550AV plotter.

\section{RESULTS}

\section{Various Types of Dividing Cells in the Young Retina}

Labeled dividing cells were found in several locations. Most were in the circumferential germinal zone (CGZ);

\footnotetext{
${ }^{3}$ Abbreviations used: C, cone; CCZ, circumferential germinal zone; $\mathrm{CP}$, cone pedicle; ELM, external limiting membrane; G, germinal cell;
}

others were scattered across the inner nuclear layer $(\mathrm{INL})$ and the outer nuclear layer (ONL). Occasionally there were labeled endothelial cells and vascular cells in the blood vessels at the vitreal surface and, more rarely, labeled glial cells in the optic fiber layer (Johns, 1982). These latter three cell types are not considered further, since they are obviously not of neuronal lineage. We are left with three different populations of dividing cells, distinguished by their characteristic locations in the retina (CGZ, INL, or ONL), which are potential sources of new neurons.

\section{Neuroepithelial Cells of the Circumferential Germinal Zone}

The labeled cells in the CGZ (Fig. 1) were typical neuroepithelial cells such as are found in the ventricular zone of the developing brain (Seymour and Berry, 1975), in the embryonic retina (Hinds and Hinds, 1974), and in the germinal zones in the optic tectum of juvenile and adult goldfish (Raymond and Easter, 1983). They were elongated spindle-shaped cells with an apical (sclerad in the retina) and a basal (vitread) process (Rivlin and Raymond, in preparation). All mitotic figures we observed in the circumferential germinal zone in the goldfish retina were located adjacent to the external limiting membrane (ELM) immediately beneath the retinal pigmented epithelium (RPE) (Fig. 1). The nuclei of the neuroepithelial cells in the CGZ were spindle-shaped, lobulated, and often contained one or more nucleoli. The chromatin distribution was heterogeneous and electron dense. There were abundant free ribosomes in the cytoplasm. The postmitotic progeny of the CGZ include cones, cells in the INL, and ganglion cells (Johns, 1977; Meyer, 1978). As shown in previous light microscopic autoradiographic studies (Straznicky and Gaze, 1971; Johns, 1977; Meyer, 1978), those cells that complete their terminal mitotic division shortly after the injection of $\left[{ }^{3} \mathrm{H}\right]$ thymidine remain in a narrow annulus distributed across all three nuclear layers.

\section{Dividing Cells in Differentiated Retina}

The main purpose of this study was to identify the labeled cells located in the ONL and INL in the differentiated, laminated retina central to the CGZ. Table 1 is a catalog of the 235 labeled cells of this type that we studied in EM autoradiographs. Only labeled cells central to the annulus of labeled progeny of the CGZ are included in this listing. The number of labeled cells per section

GCL, ganglion cell layer; INL, inner nuclear layer; IS, inner segment; M, Müller glia; ONL, outer nuclear layer; OPL, outer plexiform layer; $P$, precursor; PR, photoreceptor; $R$, rod; RPE, retinal pigmented epithelium; X, pyknotic cell. 

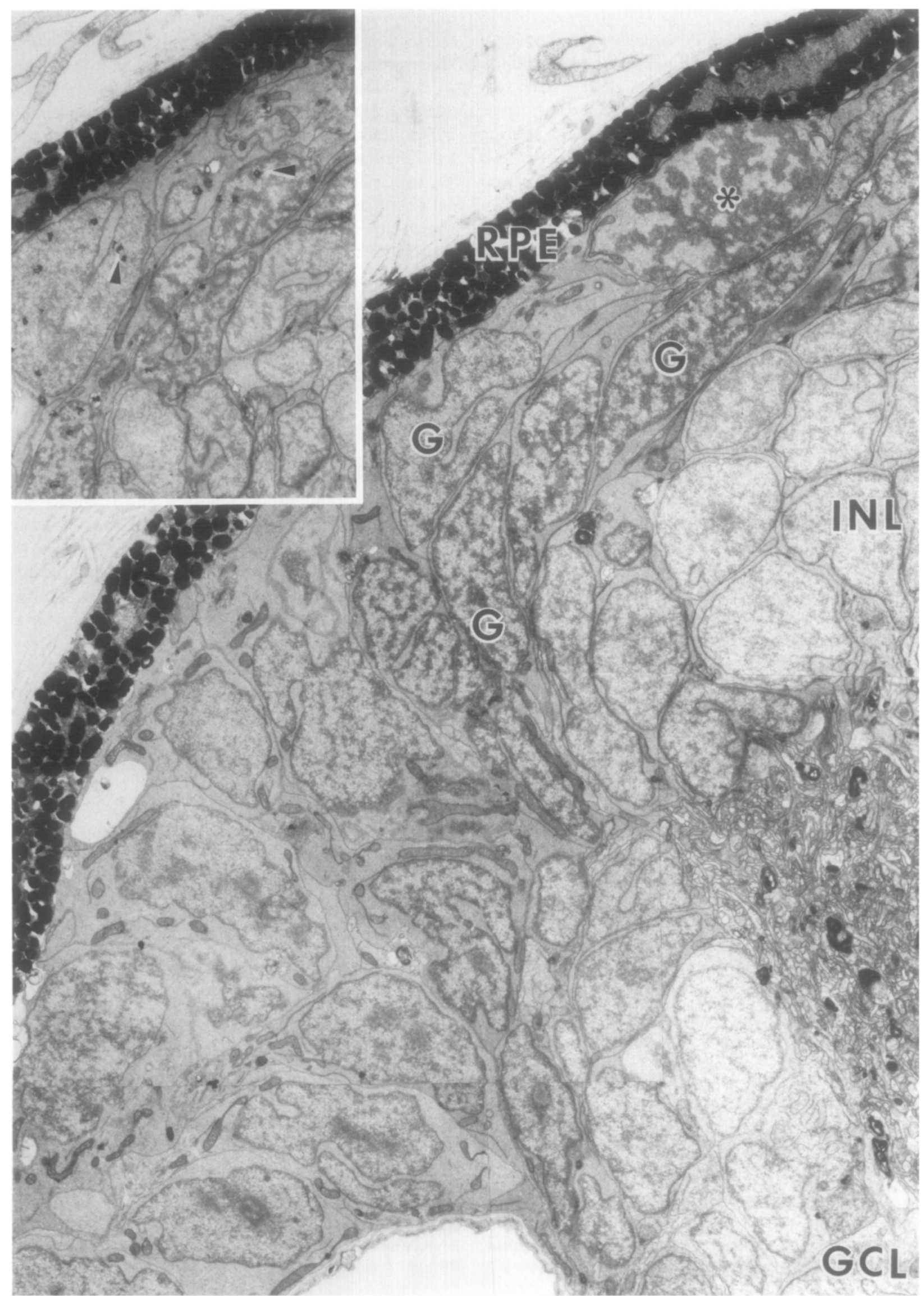
varied over a wide range, even in retinas at equivalent times after injection (Table 1). This observation is consistent with previous studies (Scholes, 1976; Johns, 1982). It probably reflects multiple factors, including variability in the dosage of tracer administered, due to, for example, the size of the fish or leakage of the tracer, as well as actual variation in the numbers of proliferating cells related to differential growth rates of individual fish (Raymond, 1985a, and unpublished observations). The apparent partitioning of labeled cells between INL and ONL also varied from one fish to another. For example, consider the three fish examined at $48 \mathrm{hr}$ after injection (44/46-1R, 51/53-2R, and 51/53-4L). The numbers of labeled cells (ONL:INL) in each section ranged from 18:3 to $6: 7$ to $10: 16$, respectively (Table 1 ). This variability reflects sampling bias due to the small sample size (only one section was examined for each of these fish). In the present study we were not attempting a quantitative evaluation of labeling patterns, but instead we sought to assemble a portfolio of EM autoradiographs from which to examine the ultrastructural features of the labeled cells. In an earlier study (Johns, 1982) we described the distribution of labeled cells based on a systematic evaluation of light microscopic $\left[{ }^{3} \mathrm{H}\right]$ thymidine autoradiographs from larval goldfish retinae. The technical difficulties of EM autoradiography, and the time consuming nature of the procedure, preclude such a systematic approach here. However, if we examine the overall distribution of labeled cells at short ( 1 to $48 \mathrm{hr}$ ) and long (9 to 14 days) intervals (see Table 1, subtotals), we find that the trends are entirely consistent with the earlier study: the proportion of labeled cells in the ONL is lower after only 2 days or less $(116 / 154=0.75)$ than after several days $(79 / 81=0.98)$.

Inner nuclear layer. The nuclei of labeled cells in the INL were typically more electron dense and heterogeneous than the nuclei of surrounding ncurons (bipolar, amacrine, and horizontal cells) or glia (Müller cells) in the INL (Figs. 2 and 3). The cytoplasm was sparse but contained abundant free ribosomes and, in retinas fixed with osmium ferricyanide, usually appeared more electron dense than the cytoplasm of the surrounding neurons (Fig. 2B). A Golgi apparatus was often present (Fig. $2 \mathrm{~B})$. The nuclei were elongated perpendicular to the retinal laminae, whereas nuclei of most nearby neurons were round (Figs. $2 \mathrm{~A}$ and $3 \mathrm{~A}$ ).
Labeled cells in the INL were typically associated with other labeled (or unlabeled) cells with a similar cytological appearance (Figs. 2A and 3). Of the 38 labeled proliferating cells in the INL listed in Table 1 (survival times of 1 to $48 \mathrm{hr}$ ) 32 were adjacent to at least one other cell of similar type. The remaining 6 , apparently solitary cells, might in fact have been located on the edge of a cluster, such that the plane of the section did not pass through the other members. Serial reconstructions showed that these cells were smooth and spindle-shaped, with a single sclerad and one or two vitread processes (Fig. 4). These processes were relatively short (up to 10 $\mu \mathrm{m})$ and tapered to fine unspecialized tips. We never found them extending into the inner plexiform layer, though some penetrated the outer plexiform layer (e.g., cluster II in Fig. 4); none reached the apical surface (ELM), however. In contrast to the CGZ, where mitotic figures were always seen along the ELM (e.g., Fig. 1), mitosis can take place in situ in the INL (Fig. 2C).

The 38 labeled INL cells in Table 1 were partitioned into 13 clusters and 6 isolated cells. The 13 clusters (containing in all 32 labeled cells) each comprised 3 or 4 cells (labeled or unlabeled) that could be seen on a single section. The labeled INL cells were typically associated with one or more Müller cells, which we never found labeled. Of the total 19 occurrences of either isolated or clustered labeled cells, over half $(11 / 19)$ were adjacent to one or more Müller nuclei. The 2 clusters that were reconstructed (labeled I and II in Fig. 4) were both associated with multiple ( 4 and 3, respectively) Müller nuclei (Figs. $2 \mathrm{~A}, 3 \mathrm{~A}$, and 4 ). The labeled cells were tightly entwined by branches of Müller cell processes (Fig. 4). Cluster II in Fig. 4, for example, extends from the INL across the outer plexiform layer (OPL) into the ONL (Figs. 3A and 4) and is accompanied all the way by radial Müller fibers (Fig. 4). The Müller cells were easily recognized by their distinctive nuclei-sharply polygonal and sometimes deeply clefted, and more homogeneous than those of the labeled cells (Fig. 5). A prominent nucleolus was often present. The cytoplasm of Müller cells was dense, and it contained abundant glycogen granules which showed a particular affinity for the osmium ferricyanide stain (Fig. 5). In some preparations, in certain regions of the retina, the osmium ferricyanide formed an opaque precipitate which completely filled the Müller cytoplasm (e.g., Fig. 5, top). Our serial reconstructions of Müller

FIC. 1. Electron micrographs of the circumferential germinal zone at the retinal margin in young juvenile goldfish. A mitotic figure (*) is seen at the top of the figure, adjacent to the external limiting membrane bordering the retinal pigmented epithelium (RPE). The differentiated retinal cells most recently formed by the germinal zone are at the right of the figure, in discrete laminae: ganglion cell layer (GCL) and inner nuclear layer (INL); the outer nuclear layer (not illustrated) is between the INL and the RPE, but commences further centrally. Neuroepithelial germinal cells $(G)$ that are not in mitosis are spindle-shaped and electron dense. 5500X. The inset shows another section from the same retina, but processed for autoradiography. The fish was injected with $\left[{ }^{3} \mathrm{H}\right]$ thymidine 12 hr before fixation. Note the silver grains (arrowheads) over the nuclei of germinal cells. $4400 \times$. 


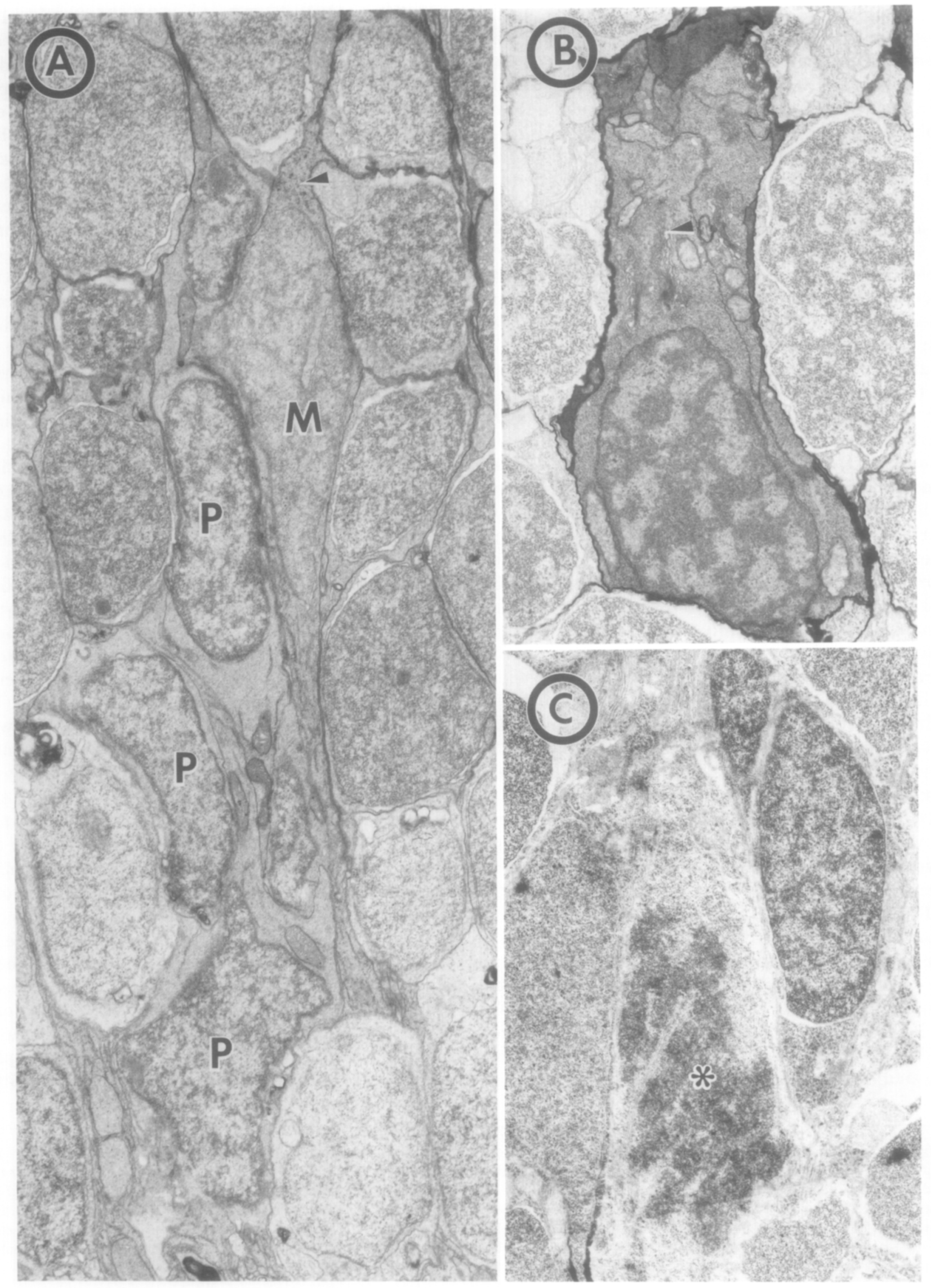



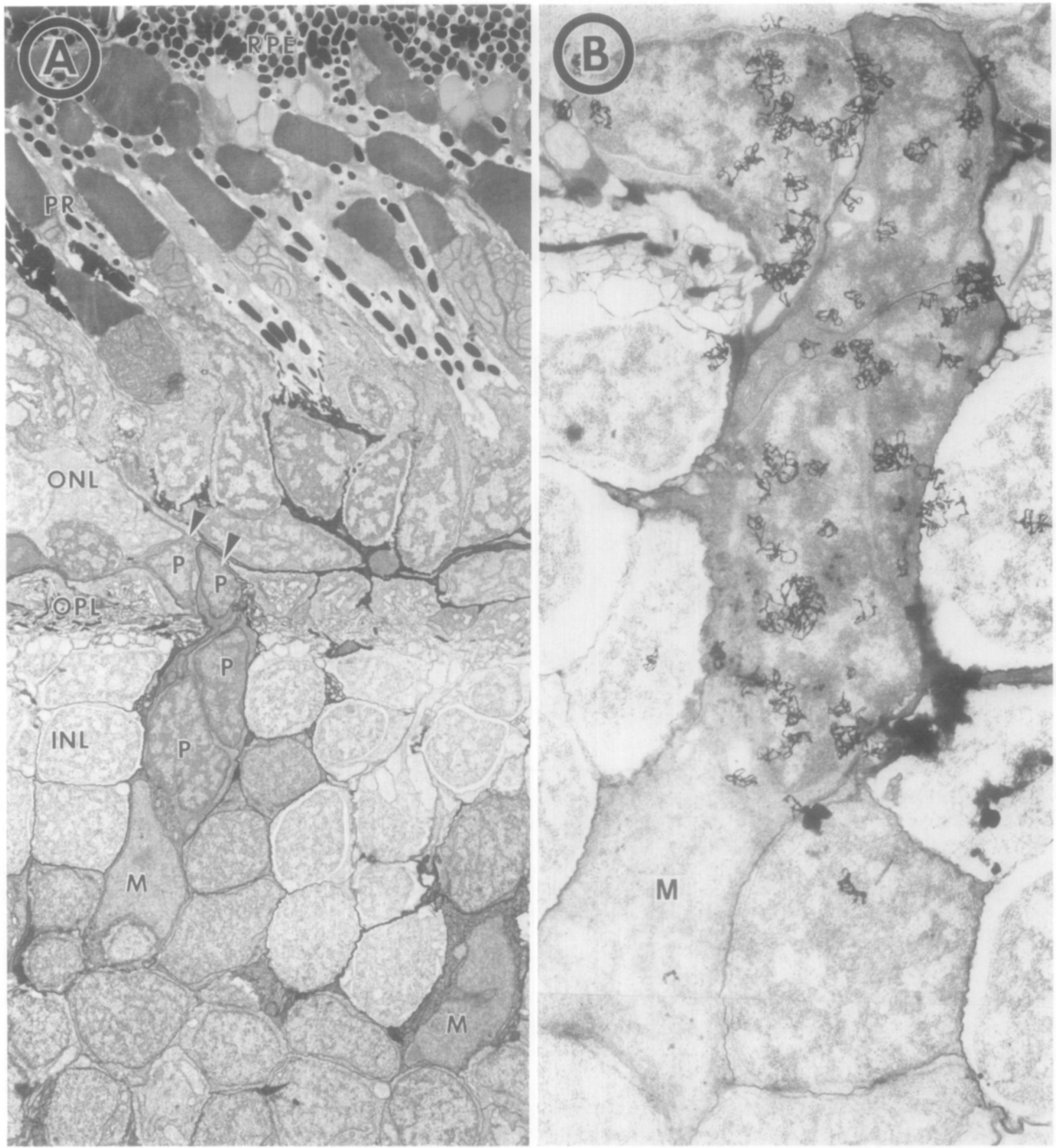

FIr. 3. Filectron micrograph and FM autoradiograph of dividing cells in the INL. (A) A cluster of elongated neuroepithelial-like cells (P) associated with a Müller glia (M). The cell cluster extends across the outer plexiform layer (OPL) into the outer nuclear layer (ONL). Arrowheads point to two cells that straddle the OPL. Photoreceptors (PR) and pigmented retinal epithelium (RPE) are at the top. 3400X. (B) A nearby section in the serial set that was processed for autoradiography. Survival time was $12 \mathrm{hr}$ after injection of [ $\left.{ }^{3} \mathrm{H}\right]$ thymidine. Four of the neuroepithelial-like cells have labeled nuclei; the Müller nucleus is unlabeled. 10,700 $\times$.

FIG. 2. Electron micrographs of dividing cells in the INL. Sclerad is up in these and all subsequent photos unless otherwise noted. $(\Lambda)$ Cluster of elongated cells $(\mathrm{P})$ that appear similar to neuroepithelial cells in the GCZ, but are located in more central, differentiated regions of retina. An adjacent Müller glia (M) has glycogen granules (arrowhead) in its cytoplasm. $8600 \times$. (B) Another example of a dividing cell in the INL. (The nucleus of this cell was labeled with $\left[{ }^{3} \mathrm{H}\right]$ thymidine in an adjacent section that was processed for autoradiography). Note the well-developed Golgi apparatus (arrowhead). In this preparation, the osmium ferricyanide precipitate is especially dense and outlines each separate cell. $12,600 \times$. (C) A mitotic figure (*) in the INL. $7500 \times$. 


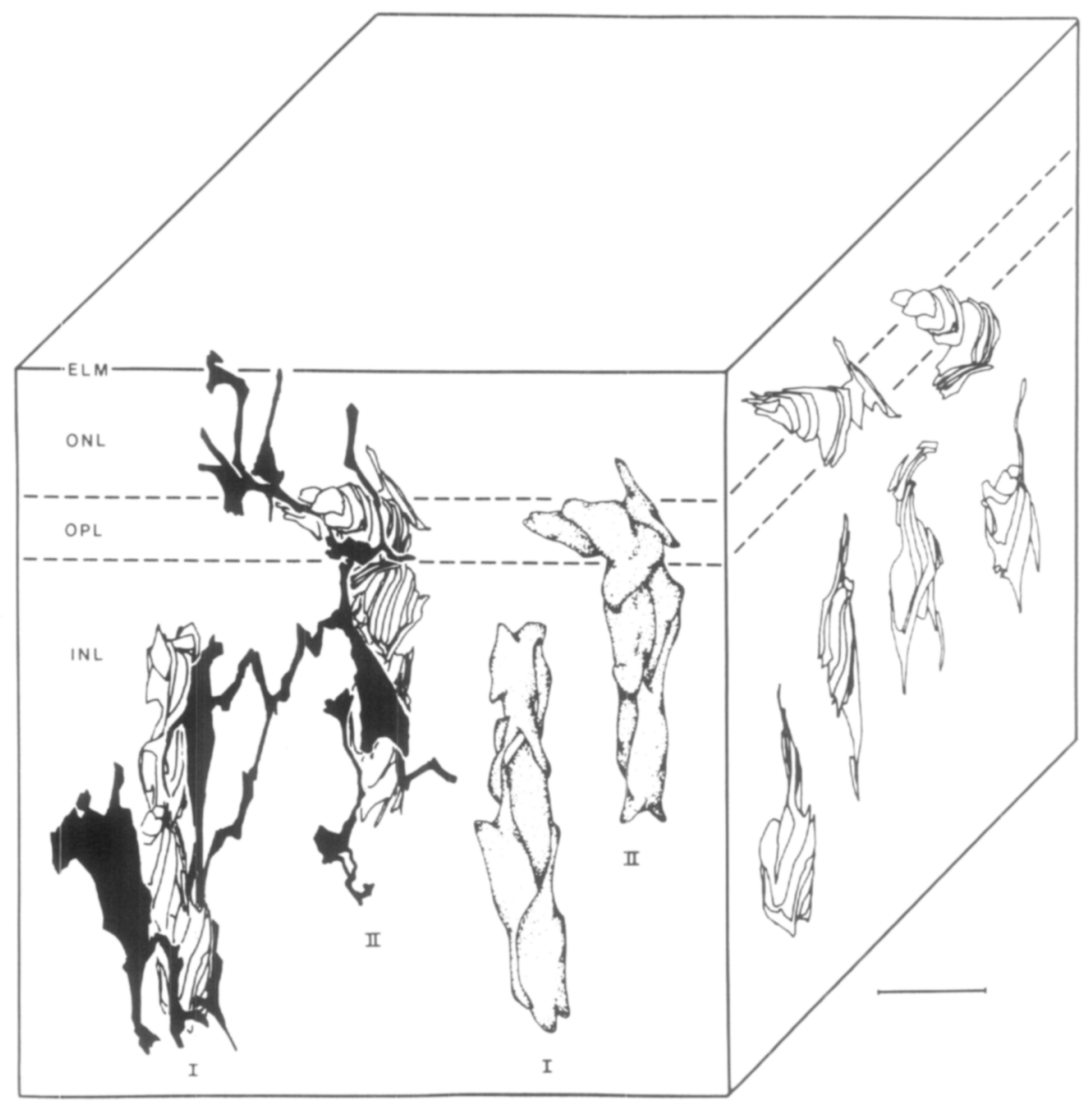

Fig. 4. Serial reconstructions of thymidine-labeled cells in the INL. On the face of the box at the left, two clusters (I and II) are reconstructed by computer graphics and shown together with the Müller cell processes (in grey) that surround them. The cell nuclei were omitted from this representation. Immediately adjacent, the same two clusters are represented in an artist's drawing, without the Müller cells. Cluster I is illustrated in Fig. 2A and is actually composed of five cells, but only four are drawn for clarity. Cluster II is the one illustrated in Fig. 3; all six cells that this group comprises are drawn here. On the side of the box, the clusters have been pulled apart and selected cells are drawn individually in computer-generated reconstructions. Calibration bar is $10 \mu \mathrm{m}$.

cell processes (not illustrated) were very similar in overall appearance to Cajal's drawings of Golgi-stained Müller cells in teleost retina (Ramón y Cajal, 1893).

The thymidine-labeled cells which were located in the OPL (Fig. 3A, arrowheads) had cytological features intermediate between those of labeled INL clusters and those typical of rod precursors in the ONL, described in the following paragraph. Furthermore, their shape was intermediate between the elongated spindle typical of labeled INL cells (Fig. 4) and the broader irregular polyhedrons typical of rod precursors in the ONL (see below, Fig. 9).

Outer nuclear layer. In the electron microscope rod precursors could be recognized as a distinct cell type, different from the surrounding differentiating and mature rods (Fig. 6). They were typically located on the vitread side of the ONL (Figs. 6, 7, and 8), as Sandy and Blaxter (1980) first observed. Their chromatin was less electron dense than that of rods (or cones), the shape of the nucleus was often irregular or lobulated, and free ribosomes and polysomes were abundant in the cytoplasm (Fig. 6A). The cell body and nucleus were sometimes flattened in the tangential plane (Figs. 6 and 9). They could be labeled with $\left[{ }^{3} \mathrm{H}\right]$ thymidine, indicating that they were mitotically active (Figs. $6 \mathrm{~B}, 7,8 \mathrm{~A}$, and 8B). The labeled cells were found singly (Fig. 6B), in pairs (Fig. 8B), or rarely in clusters (Fig. 7). Of the 147 labeled precursors in the ONL (Table 1, survival times of 1 to $48 \mathrm{hr}$ ), 28 were paired, and there were 2 clusters which comprised 3 and 4 cells, respectively. Labeled pairs were common at survival times of 24 and $48 \mathrm{hr}$ (Fig. 8B); these probably represent daughter cells of a single division. The remaining 108 labeled cells occurred singly, though it is possible that at least some of these were actually members of pairs, with the other member behind or in front of the section examined. Compared to 


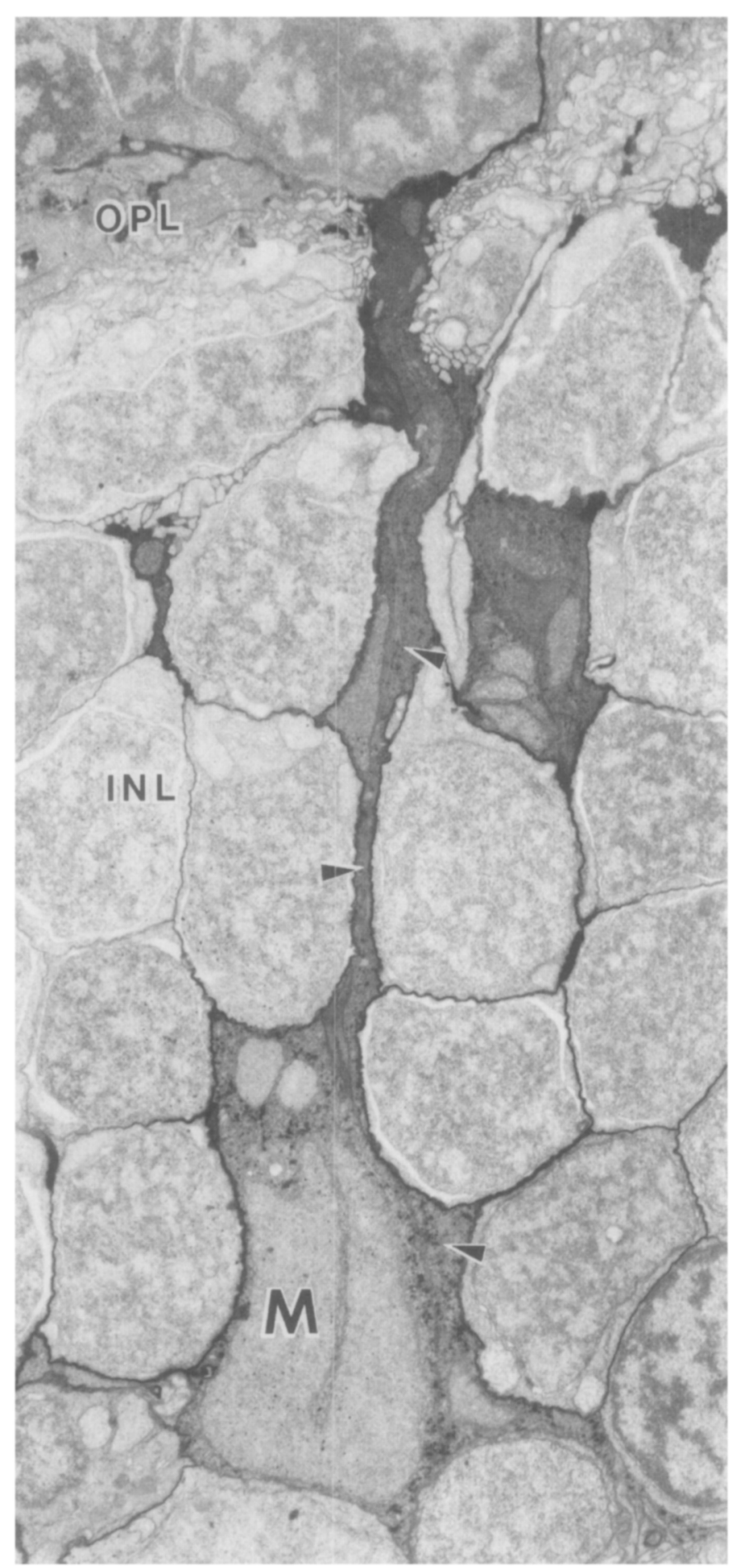

FIG. 5. Electron micrograph of a Müller cell with nucleus in the INL. This preparation was not stained en bloc with uranyl acetate. Note the glycogen granules (arrowheads) and the long apical process that crosses the outer plexiform layer (OPL). $6700 \times$.

labeled cells in the INL, those in the ONL appeared to exhibit less tendency to cluster ( 35 out of 147 in the ONL versus 32 out of 39 in the INL).
At survival times of 12 and $24 \mathrm{hr}$, labeled mitotic figures were seen along the vitread border of the ONL (Fig. $8 \mathrm{~A}$; Table 1), but rarely adjacent to the ELM. Labeled dying cells with pyknotic nuclei were also seen in the ONL during the first $48 \mathrm{hr}$ following injection (Figs. 8C and 8D; Table 1). Dying cells were also common in the CGZ (not shown).

Computer-aided reconstructions showed that the labeled rod precursors in the ONL had one (sometimes two) sclerally directed process(es) but no vitread process (Fig. 9). These processes ended blindly in the ONL; we never observed them extending to the external limiting membrane. The surfaces of the rod precursors often had short ridges or fins that protruded laterally a few micrometers (Fig. 9). In this respect they differed from the smooth streamlined precursor cells in the INL.

\section{Progeny of Precursor Cells in Differentiated Retina}

As early as 9 days following thymidine injection labeled cells had begun to differentiate into rods. The stages in the development of rods in the larval goldfish were described in a previous publication (Raymond, 1985b). Rods, even immature ones, can be distinguished from cones based on several cytological and ultrastructural features (Figs. 6B and 7). Briefly, these are an ovoid, electron dense nucleus positioned in a stratum vitread to the row of cones along the ELM, an electron dense cytoplasm, a perinuclear synaptic ribbon and accumulation of synaptic vesicles, and an apical (myoid) process containing an elaborate stack of parallel arrays of rough endoplasmic reticulum. Depending on the plane of section, some or all of these features were seen on all cells $(n=79)$ with labeled nuclei in the ONL at 9 and 14 days after injection (Fig. 10). We have not reconstructed these labeled rods.

No labeled cone nuclei or ganglion cells were found central to the labeled band of cells produced by the CGZ. In a previous light microscopic study (Johns, 1982) we found that a few labeled cells remained in the INL at longer intervals after injection, but thus far, we have found only two of these in our EM autoradiographic material (Table 1). The identity of these cells has not yet been established. They appeared to be associated with Müller/precursor clusters, but their ultrastructural features were not like either of these two cell types. Their nuclei were rounded with homogeneous chromatin, whereas precursors had heterogeneous chromatin, and their cytoplasm was pale and free of glycogen granules, which Müller cells had in abundance. We found in the previous thymidine study (Johns, 1982) that labeled nuclei in the INI, eventually (after many months) virtually disappear, whereas labeled rods in the ONL remain for months (possibly years) after an injection of $\left[{ }^{3} \mathrm{H}\right]$ thymidine. 


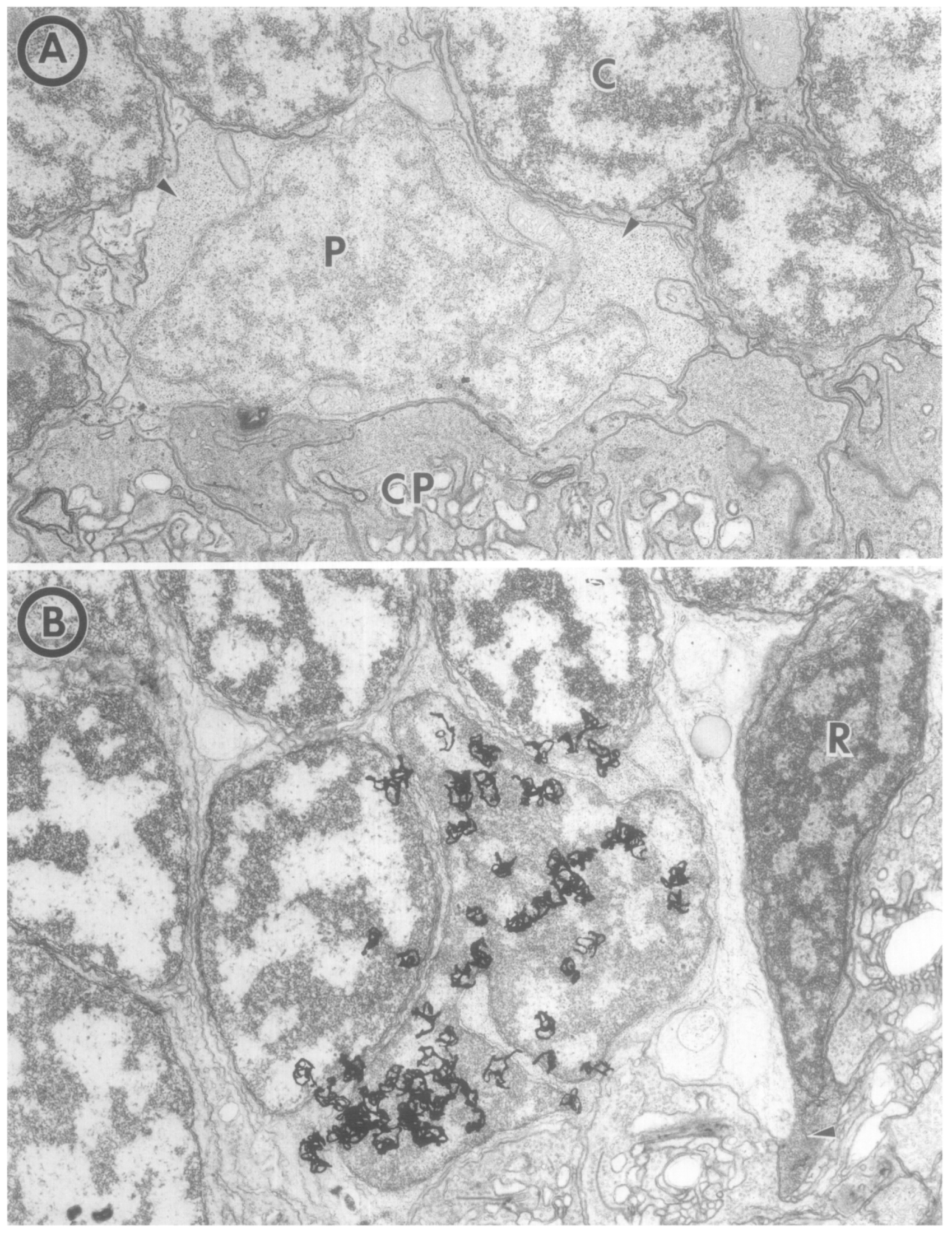

Fig. 6. Electron micrographs of dividing cells in the ONL. (A) The rod precursor (P) has a pale nucleus and cytoplasm, with abundant free ribosomes (arrowheads). Nuclei of cones (C) and synaptic terminals of cones, called cone pedicles (CP), surround it. 15,300 $\times$. (B) A rod precursor labcled with $\left[{ }^{3} \mathrm{H}\right]$ thymidine at $12 \mathrm{hr}$ after injection. A young rod (R) with developing synaptic terminal (arrowhead) lies nearby. This mierograph is tilted so that sclerad is toward the upper left corner. $15,300 \times$. 


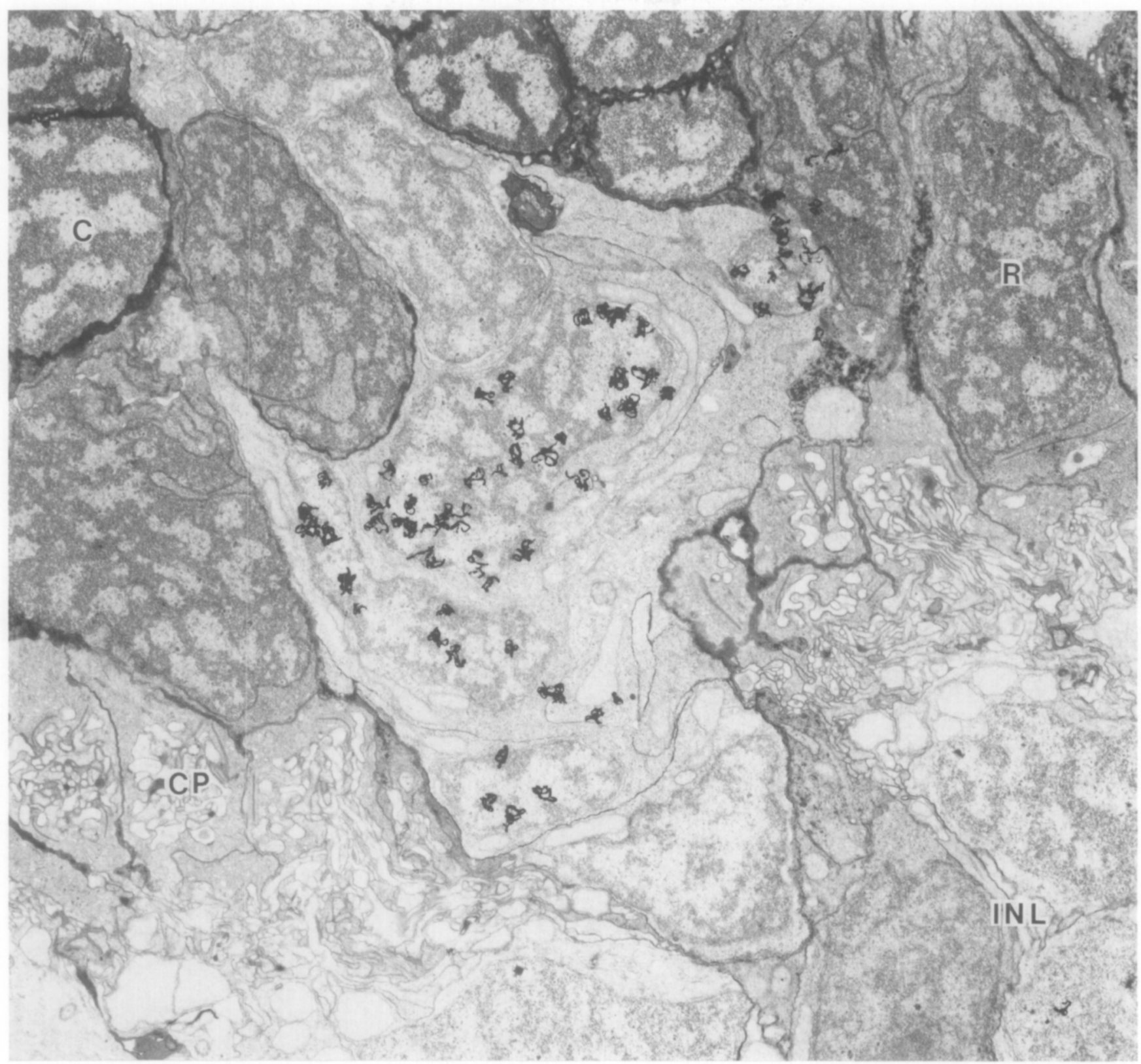

FIG. 7. EM autoradiograph of a cluster of dividing rod precursors in the ONL. Four nuclei labeled at $12 \mathrm{hr}$ after $\left[{ }^{3} \mathrm{H}\right] \mathrm{thymidine}$ injection are seen, surrounded by unlabeled nuclei of cones $(C)$, rods $(R)$, and cone pedicles (CP). This labeled cluster extends into the INL. 10,600X.

\section{Summary}

Figure 11 summarizes our observations from EM autoradiography and serial reconstructions. We found two types of dividing cells in central regions of the larval retina: clusters in the INL and single scattered cells in the ONL. The clusters or nests of cells in the INL $\left(\mathrm{P}_{1}\right.$ in Fig. 11) were oriented perpendicular to the retinal laminae, and the cells themselves were elongated in this dimension and spindle-shaped. Sometimes these clusters of tightly packed cells extended from the INL across the
OPL into the ONL. It is likely that these clusters are composed of clonally related cells, but this has yet to be demonstrated. $\Lambda$ ll of the labeled INL cells, including those that were reconstructed from serial sections as well as those observed in single sections (see Table 1), were closely associated with Müller fibers (Fig. 11).

The dividing cells in the ONL ( $\mathrm{P}_{z}$ in Fig. 11) differed from those in the INL in arrangement, shape, and ultrastructure. $\mathrm{P}_{2}$ cells tended to occur singly or in pairs that likely represent the daughter products of a single mitotic division (e.g., Fig. 8B). They tended to be less 

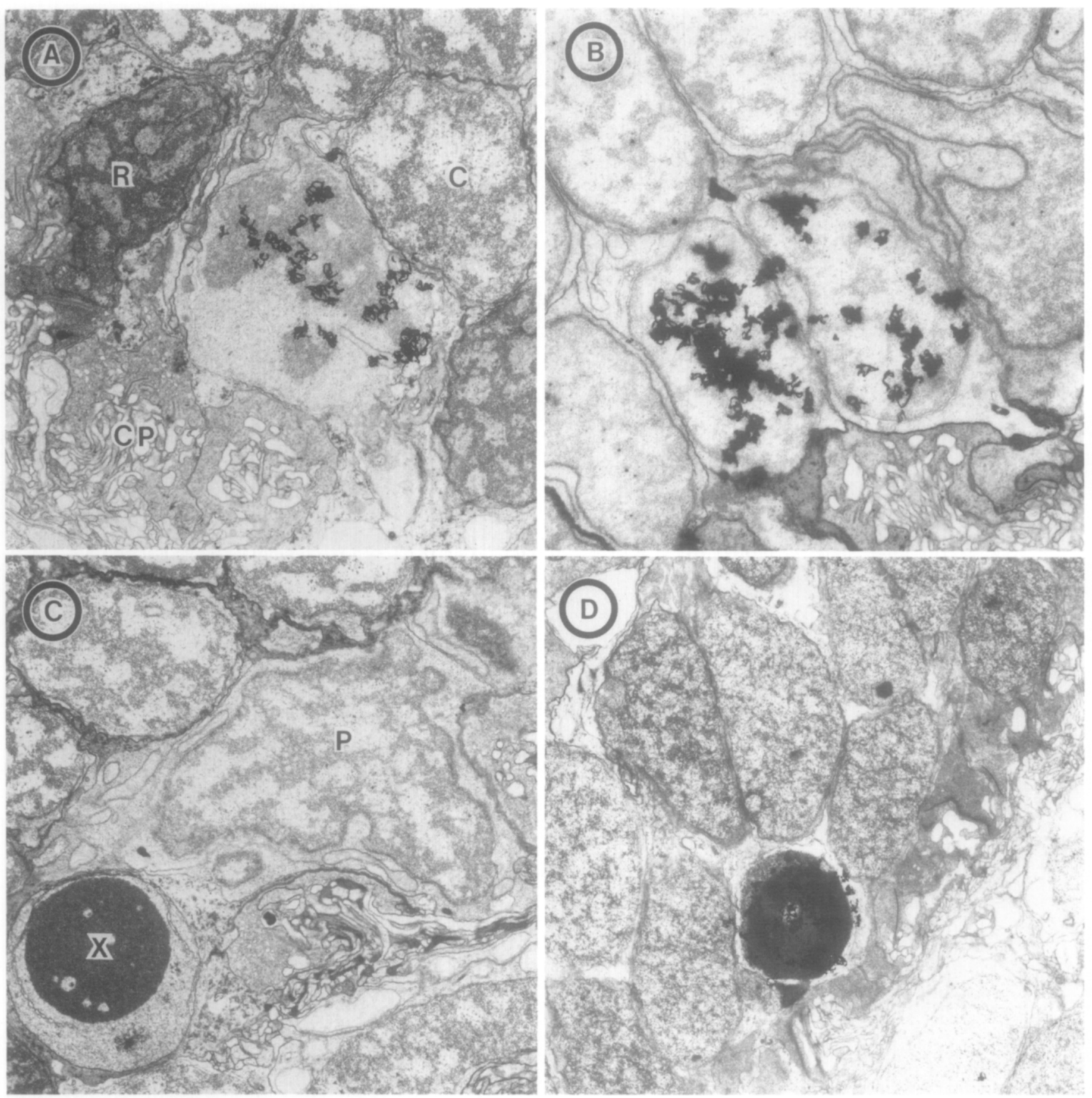

FIG. 8. Electron micrographs depicting mitosis and eell death in the ONL. ( $\Lambda$ ) Mitotic figure labeled at $12 \mathrm{hr}$ after [ $\left.{ }^{3} \mathrm{H}\right]$ thymidine injection. Other abbreviations are as in Fig. 7. 9200×. (B) Labeled daughter pair at $48 \mathrm{hr}$ after $\left[{ }^{3} \mathrm{H}\right]$ thymidine injection. 8700 $\times$. (C) Pyknotic cell (X) adjacent to rod precursor (P). $8700 \times$. (D) Pyknotic cell labeled at $24 \mathrm{hr}$ after $\left[{ }^{3} \mathrm{H}\right]$ thymidine injection. $7100 \times$. Sclerad is toward the upper right in $(A)$ and toward the upper left in $(B),(C)$, and $(D)$.

electron dense than $P_{1}$ cells and irregular or polygonal in shape. There was, however, a continuum of morphological attributes linking INL and ONL precursors that was expressed in those cells which penetrated or straddled the intervening OPL (e.g., Figs. 3A, 7, and 8C). Whether the morphological differences between $\mathrm{P}_{1}$ and
$\mathrm{P}_{2}$ precursors reflect different developmental capacities is unknown.

\section{DISCUSSION}

During postembryonic growth of the retina in teleost fish the outer nuclear layer increases in thickness, and 


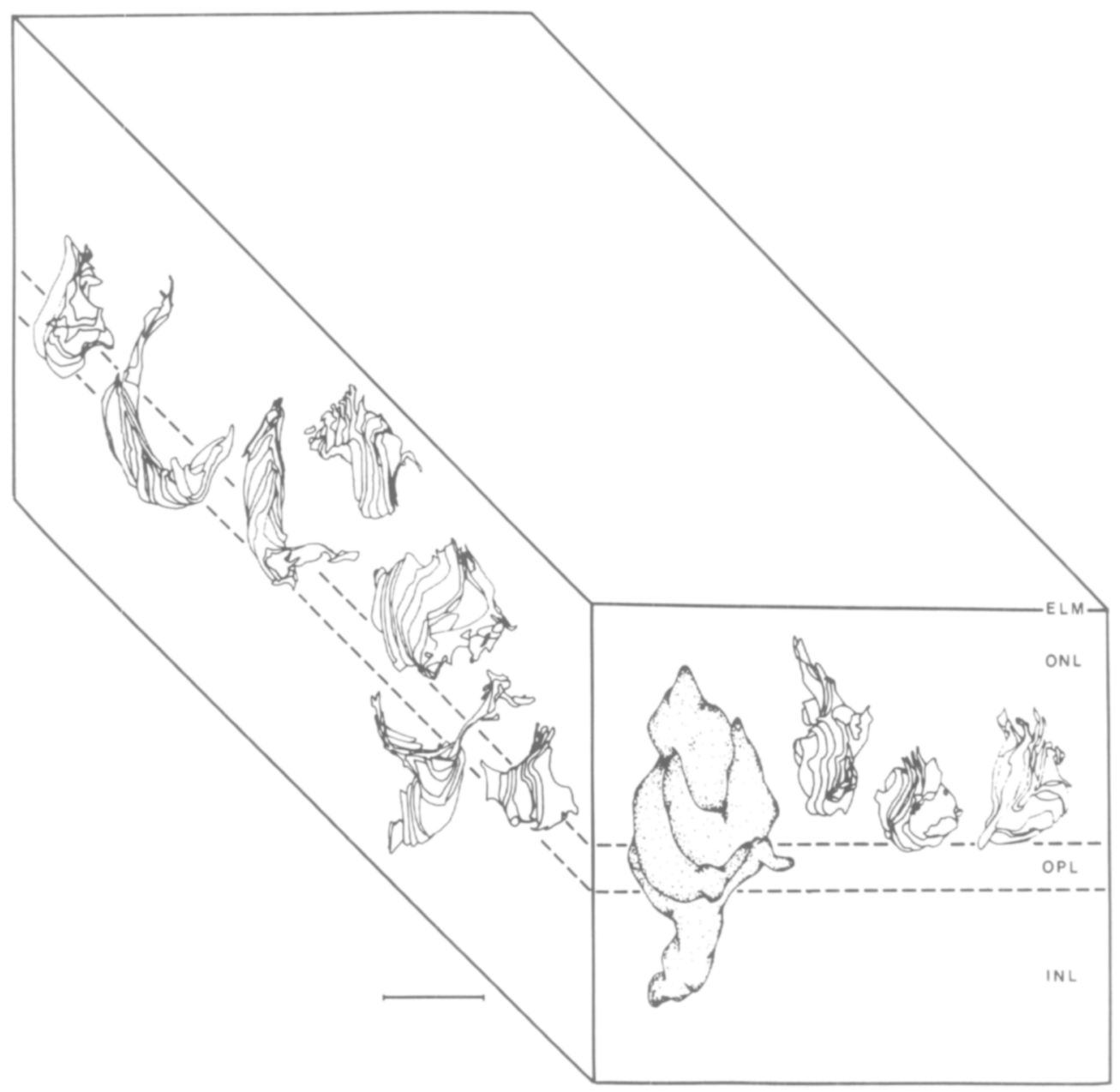

FIG. 9. Serial reconstructions of thymidine-labeled dividing rod precursors in the ONL. On the side of the box that faces the reader are three isolated labeled precursors (computer reconstructions) and a cluster of four labeled precursors (artist's drawing from a computer reconstruction). This same cluster was illustrated in Fig. 7. The group actually contained eight cells, but only four are drawn here for clarity. On the side of the box the cluster has been pulled apart and computer reconstructions of seven of the eight cells that it contained are plotted individually. Calibration bar is $10 \mu \mathrm{m}$.

this increase reflects addition of rods (Vilter, 1947; Müller, 1952). The origin of the new rods that appear everywhere across the already differentiated retina remaincd unexplained for almost 30 years after it was first described. There had been early reports of mitotic figures in the ONL (Vilter and Lewin, 1954; Lyall, 1957; Ahlbert, 1973, 1976), but their apparent scarcity made it seem unlikely that they could be responsible for the large increase in the number of rods seen during postembryonic life. Recent studies using $\left[{ }^{3} \mathrm{H}\right]$ thymidine autoradiography showed that dividing cells persist in the ONL of the retina in adult fish (Sandy and Blaxter, 1980; Johns and Fernald, 1981) and that the progeny of these cells differentiate into rods (Johns, 1982). The autoradiographic studies made it clear that dividing cells, called rod precursors, were abundant in the ONL, especially in juvenile fish (Johns, 1982), and could account for the increase in rods.
There remained a puzzle, however. When retinas from newly hatched goldfish were examined with both light (Johns, 1982) and electron microscopy (Raymond, 1985b) it became apparent on morphological grounds that the ONL at hatching consisted of a single row of young differentiating cone nuclei, with no rods or rod precursors. Furthermore, no cells in the ONL in these young animals incorporated $\left[{ }^{3} \mathrm{H}\right]$ thymidine (Johns, 1982). Therefore, it was concluded that rod precursors must initially be located elsewhere. The two obvious places from which dividing cells could be recruited were the margin of the retina (the circumferential germinal zone where a mitotically active neuroepithelium persisted) and the inner nuclear layer. If the germinal zone were the immediate source of rod precursors that eventually populated the early larval retina, then rod precursors would first appear in the ONL close to the margin, and only later in the center. In contrast, the autoradiographs showed that 


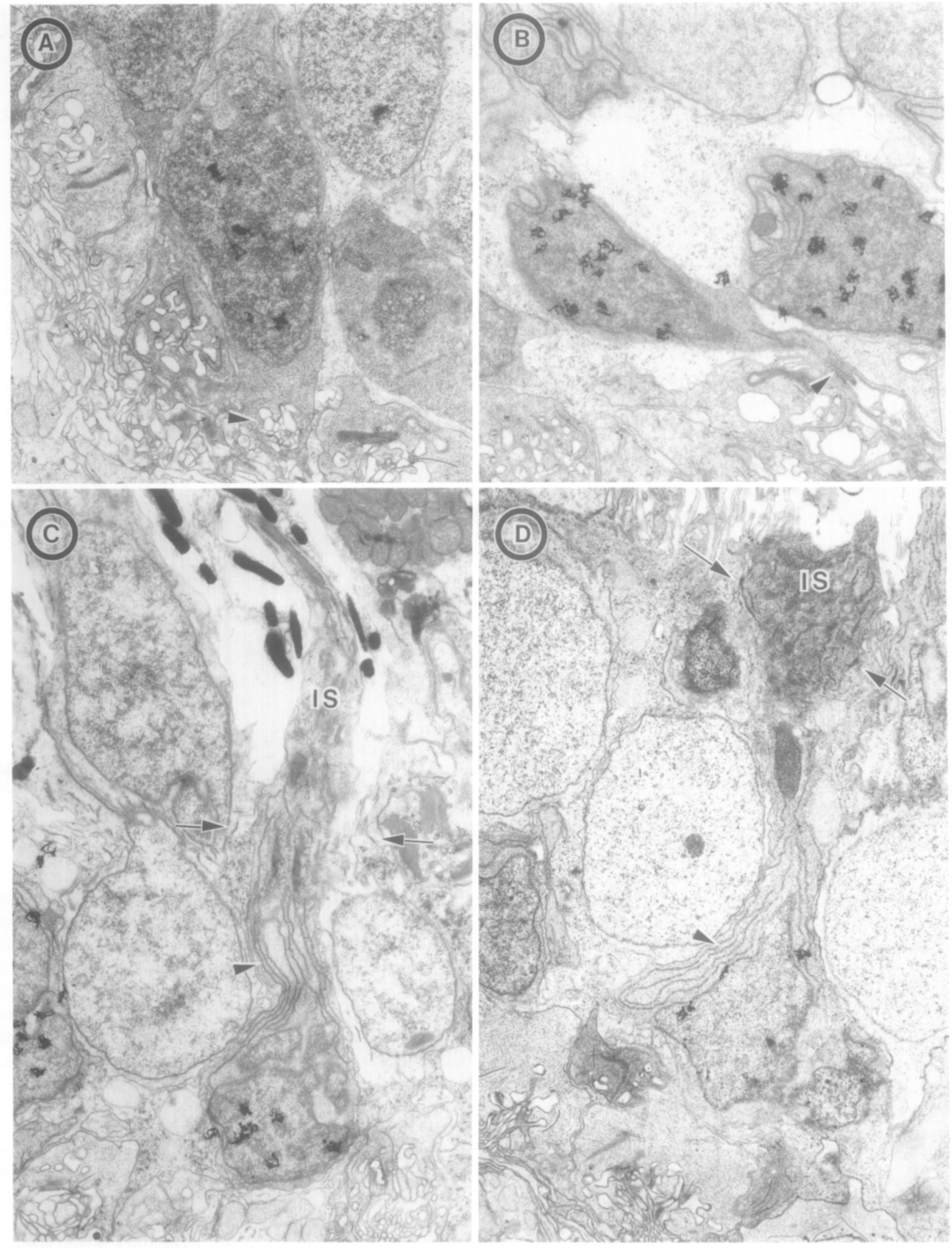

FIG. 10. EM autoradiographs of young rods labeled with $\left[{ }^{3} \mathrm{H}\right]$ thymidine. Survival time was nine days after injection. (A) Labeled nucleus in a rod with developing synaptic terminal (arrowhead). (B) Two labeled rod nuclei, one with a synaptic ribbon (arrowhead). (C) Labeled rod nucleus with apical stacks of rough endoplasmic reticulum (arrowhead) and developing inner segment (IS) penetrating the ELM (arrows). (D) Labeled rod nucleus similar to the one in (C). $7800 \mathrm{x}$. 


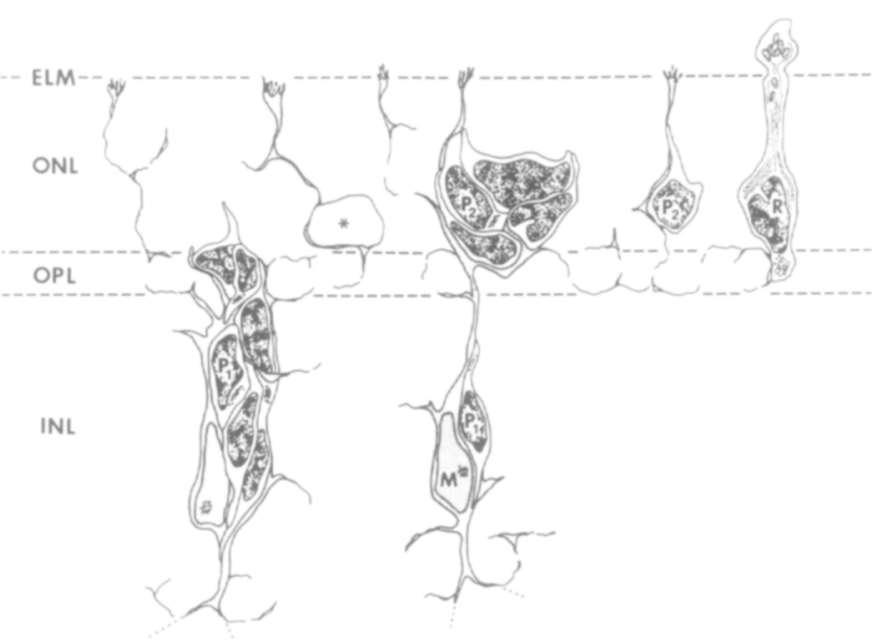

FIG. 11. Semischematic diagram illustrating proposed sequence of rod ontogenesis in the goldfish retina. (See text for details).

they appeared everywhere at once. The conclusion was that rod precursors do not come from the germinal zone. The INL seemed a more likely candidate since earlier work, in which cells were counted in retinas of different aged fish, had shown that cells were preferentially lost from the INL during postembryonic growth in goldfish (Johns and Easter, 1977). Blaxter and co-workers (Blaxter and Jones, 1967; Blaxter and Staines, 1970) had made similar observations in several species of marine teleosts. They proposed that the INL provided a reservoir of undifferentiated cells that later migrated into the ONL where they differentiated into rods (without further cell divisions).

Autoradiographic studies on larval goldfish showed that undifferentiated cells in the INL hypothesized by Blaxter did indeed exist, and moreover, they were still mitotically active (Johns, 1982). Furthermore, the dividing cells in the INL tended to disappear with age. That is, an injection of $\left[{ }^{3} \mathrm{H}\right]$ thymidine preferentially labeled cells in the INL in larval animals, but in older fish, dividing cells in the ONL (rod precursors) were more prominent. When fish were allowed to survive for weeks or months after an injection of $\left[{ }^{3} \mathrm{H}\right]$ thymidine, it was found that many rods in the ONL were labeled no matter what the age of the fish at injection, but not as many labeled cells could be found in the INL. The identity of those that did persist in the INL could not be determined with light microscopic histology.

There are several possible ways to explain the loss of dividing cells (cells which incorporate $\left[{ }^{3} \mathrm{H}\right]$ thymidine) and the loss of labeled progeny (cells which differentiate and thus retain the radiolabel) from the INL during postembryonic development, but it is more difficult to account for the simultaneous loss of both dividing cells and their differentiated progeny. If cells in the INL con- tinued to divide but never produced any differentiated progeny, then the label would be lost through dilution. But this would be inconsistent with the observation that the number of dividing cells in the INL is also diminished in older fish, since mitotic cells must continue to divide if their label is to be diluted, and if they are dividing, a subsequent injection of $\left[{ }^{3} \mathrm{H}\right]$ thymidine could relabel them. Fur thermore, heavily labeled cells, though scarce, were observed in the INL up to several months after injection, whereas the label dilution hypothesis would predict that only lightly labeled cells, or no labeled cells, would be found at these survival times. Another explanation for the loss of labeling in the INL might be that dividing cells and/or their labeled progeny die. The previous study (Johns, 1982) did not provide any evidence either for or against this hypothesis, although the present study does (see later). There are still other possible explanations, such as a prolongation in the length of the cell cycle in dividing cells in the INL compared to those in the ONL during postembryonic development. Such an increase in the length of the cell cycle by prolonging the resting $\left(\mathrm{G}_{1}\right.$ or $\left.\mathrm{G}_{2}\right)$ phases would tend to reduce the number of labeled cells seen after a pulse injection, since a smaller proportion of the population would be in S phase (the phase of DNA synthesis) at any given moment. At present we have no information about the cell cycle length of dividing cells in the INL and only a crude estimate for those in the ONL (Johns, 1982). A final possibility is that the labeled cells in the INL could be lost because they migrate out of the layer. It is this hypothesis which was most consistent with the earlier data (Johns, 1982). When the proportion of labeled cells in the ONL versus those in the INL was plotted as a function of time after $\left[{ }^{3} \mathrm{H}\right]$ thymidine injection, this proportion was found to increase. This result could be explained if labeled cells were to leave the INL and migrate into the ONL. Vertically elongated, immature cells, in some cases radiolabeled, were sometimes observed spanning the outer plexiform layer between INL and ONL. Since such cells are almost never seen in mature adult retina, it was presumed that they were transient immature elements. Although one cannot with confidence infer cell migration from such histological observations, the streamlined appearance of these cells was consistent with the possibility that they were moving from the INL to the ONL. Furthermore, quantitative analysis of the autoradiographs produced from fish injected at various ages and allowed to survive for various periods corroborated the notion that dividing labeled cells were disappearing from the INL and accumulating in the ONL (Johns, 1982).

Taken together these observations supported the following hypothesis, as proposed in the previous study (Johns, 1982). Simply stated it is this. As the embryonic 
retina differentiates some cells fail to follow the majority, but instead remain undifferentiated and mitotically active. These cells are initially sequestered in the INL, but later, as larval development progresses, they migrate into the ONL where they continue to divide. Some of the progeny of the dividing cells in the ONL differentiate into rods. Other progeny continue dividing, thereby replenishing the rod precursor pool, which persists into adulthood. Rare dividing cells may persist in the INL for several months, but they do not make any obvious contribution to the population of cells in the INL.

The present observations from serial EM reconstructions provide additional support for this hypothesis. The evidence is necessarily suggestive, not conclusive, since the micrographs provide only a snapshot of the events taking place at a given moment. The new information added by this study is morphological. We used $\left[{ }^{3} \mathrm{H}\right]$ thymidine to label dividing cells, as before, and then studied them in EM autoradiographs and reconstructed some of them in serial sections. Table 1 lists the 235 labeled cells we looked at, gathered from 11 retinae. We must caution the reader that, with the exception of those that were reconstructed, labeled cells were typically studied in a single section from each retina, and therefore the absolute numbers of labeled cells observed in a given retina and the partitioning of these cells between INL and ONL do not necessarily reflect the actual distribution of labeled cells in that retina. Thus the numbers in Table 1 do not in every case agree with the distributions reported previously (Johns, 1982). This is only a sampling problem, and since we are not relying on these data for quantitative purposes, the numbers are not important.

Figure 11 is a summary of our observations from serial reconstructions showing the morphology of labeled cells in the INL and ONL. These observations are in full agreement with the hypothesis of cell migration from the INL to the ONL. We suggest that Fig. 11 can be viewed as a life history of rods. Time moves from left to right: undifferentiated cells in the INL ( $\mathrm{P}_{1}$ in Fig. 11) are progenitors for rod precursors in the ONL $\left(\mathrm{P}_{2}\right.$ in Fig. 11) which are responsible for producing rods. The streamlined contours of the $\mathrm{P}_{1}$ precursors and their vertically elongated shape are consistent with a migratory behavior (Rakic, 1971, 1972). Another observation which supports this hypothesis is that cells located in or near the OPL have features in common with both $\mathrm{P}_{1}$ and $\mathrm{P}_{2}$ precursors. Furthermore, as stated above, cells with this shape and position are not found in adult retina; the only cells that occupy this layer in adult retina are horizontal cells, whose shape and ultrastructure differ markedly from the labeled precursors (c.f. Wolburg and Kurz-Isler, 1977). The suggestion that the latter are transitory cells passing through the OPL would explain their absence from mature retina.

With regard to the possibility raised above that labeled cells in the INL might disappear because they die, in our electron micrographs we were able to easily identify dying cells in the ONL, but we did not see any in the INL (see Table 1 and Figs. $8 \mathrm{C}$ and $8 \mathrm{D}$ ). Those in the ONL were no doubt abortive rods. Cell death is often observed in conjunction with cell genesis, and it is thought that those cells which fail to progress properly through the steps of differentiation are eliminated (Glücksmann, 1940).

An unexpected and very interesting finding in this study was the close association of $\mathrm{P}_{1}$ precursors with Müller fibers. This intimate relationship of the supposed migrating cells with the vertically oriented (radial) Müller fibers suggests that the migrating cells might be using the Müller fibers as guides in much the same way that migrating young neurons use radial glial fibers to reach the cortical layers of the developing cerebrum (Rakic, 1972) and the internal granular layer of the immature cerebellum (Rakic, 1971). The morphology of Müller cells is similar to that of radial glia, and Cajal thought the two cell types were homologous (Rámon y Cajal, 1909). Furthermore, the bipolar shape of $P_{1}$ precursors is strikingly reminiscent of young migrating cortical neurons; both have short (less than $200 \mu \mathrm{m}$ ) leading processes with an unspecialized tip lacking a growth cone (Rakic, 1972).

In this study we also provide additional evidence, that is, ultrastructural observations, in support of the conclusion that rod precursors produce rods, not cones. Earlier studies had examined autoradiographic preparations with light microscopy only (Johns, 1982; Raymond, 1985a). In the EM autoradiographs all of the labeled cells we observed in the ONL at 9 or 14 days after injection ( $n=79$, Table 1 ) could be identified as immature rods on the basis of criteria established in a previous electron microscopic description of the stages of photoreceptor differentiation in larval goldfish (Raymond, 1985b).

There are many remaining unanswered questions. From the data at hand we cannot extrapolate the lineage history of rods. We do not know whether, for example, the products of each cell division are one rod and one precursor, as would be characteristic of a stem cell lineage (Heathcote and Sargent, 1984). Since rod precursors continue to produce rods even in adults (Johns and Fernald, 1981), it is clear that some of their progeny do not differentiate but instead continue to divide. What fraction do so cannot be predicted from the autoradiographic data available. To make such predictions requires an analysis of grain densities overlying labeled cells as a 
function of the interval after injection. This has not yet been done in the teleost retina. We also do not know whether $\mathrm{P}_{1}$ precursors in the INL can give rise directly to rods, that is, whether cells which complete their terminal division in the INL can move into the ONL and differentiate into rods without undergoing further divisions. If such a mechanism exists, it must not be very significant in older fish (juveniles and adults) since the level of mitotic activity in the INL is very low compared to that in the ONL at these ages, but nevertheless rods continue to accumulate (Johns, 1982). Finally, the $P_{1}$ precursors remain an enigma in many respects. We doubt that the only role they play is to provide a source of rod precursors for the ONL. The uncertainty arises because some labeled cells persist in the INL at long survival times after $\left[{ }^{3} \mathrm{H}\right]$ thymidine injection (Johns, 1982; and Table 1). Because these cells are scarce, we have not had sufficient opportunities to study them in EM autoradiographs, and so we are unable to identify them at present.

Unlike neuroepithelial cells in the CGZ, $\mathrm{P}_{1}$ and $\mathrm{P}_{2}$ precursors divide in situ, not at the ELM. Furthermore, both $\mathrm{P}_{1}$ and $\mathrm{P}_{2}$ precursors have lost their attachment to the apical surface, which primitive neuroepithelial cells retain, and which serves as a conduit for their nucleus to migrate to the apical surface (ELM) to divide (Sauer, 1936; Fujita, 1962). In both respects, the rod precursors resemble cells in the developing CNS classified as subventricular cells (Boulder Committee, 1970; Sidman and Rakic, 1973). The formation of a secondary subventricular layer does not occur everywhere in the developing brain, but where it does occur, two separate phases of neurogenesis can be recognized, the first, ventricular, and the second, subventricular (Boulder Committee, 1970). The idea that retinal histogenesis might involve two waves of cell proliferation, spatially and temporally separate, is novel (Scholes, 1976; Raymond, 1985a). Thus far, this suggestion can be applied only to the teleost retina, where formation of rods by rod precursors is delayed and prolonged. In the mouse retina, however, $\left[{ }^{3} \mathrm{H}\right]$ thymidine autoradiography has shown that rods are the last retinal neurons to be formed and most are born postnatally (Carter-Dawson and LaVail, 1979). This could be construed as similar to, but not as extreme as, the situation in fish. In the mouse, the progenitor cells for rods are not known, and the properties of the dividing cells during the later stages of retinal histogenesis in mammals have not yet been investigated.

Although the observations we report here are confined to larval goldfish, we anticipate that the description we have provided will also apply to rod genesis in the peripheral growth zone of the retina in juvenile and adult fish. In all respects examined thus far, growth by cell addition from the CGZ mimics retinal development in larval and juvenile fish (Müller, 1952; Lyall, 1957; Johns, 1981, 1982; Raymond, 1985a,b). However, until this region is examined carefully with EM autoradiography we cannot be certain that the patterns are identical to those we have described here.

The rod precursor in the teleost retina is, to our knowledge, the first example of a neuronal germinal cell in the vertebrate central nervous system whose progeny differentiate into a single type of neuron. The standard scheme of neurogenesis describes a pluripotent homogeneous population of germinal cells in the early neuroepithelium, including the presumptive neural retina, which gives rise sequentially to various types of neurons (reviewed by the Boulder Committee, 1970). The rod precursor, in contrast, produces only rods, and therefore may be considered a specialized germinal cell. Whether this apparent specialization actually represents a restriction of developmental potentials is uncertain. The commitment to become a rod may have already been made by the mitotic rod precursors or, on the other hand, the environment of the ONL might provide certain signals dictating that all immature cells produced there differentiate into rods. We cannot yet distinguish between these two alternatives.

We thank Dr. Roberta Pourcho for her valuable advice on methods for EM autoradiography, and Dr. Peter Sterling for his counsel on serial reconstruction techniques. Mr. James Kilgore and Mr. Greg Holt provided expert technical assistance with the computer graphics. Drs. Stephen Easter and Kate Barald offered comments on the manuscript, which Mrs. Sharon Moskwiak typed. This research was supported by PHS EY04318; P.A.R. is a Fellow of the Alfred P. Sloan Foundation.

\section{REFERENCES}

AhlBERT, I.-B. (1973). Ontogeny of double cone cells in the retinae of perch fry (Perca fluviatilis, Teleostei). Acta Zool (Stockholm) 54, 241254.

AHLBERT, I.-B. (1976). Organization of the cone cells in the retinae of salmon (Salmo salar) and trout (Salmo trutta trutta) in relation to their feeding habits. Acta Zool. (Stockholm) 57, 13-35.

BEACH, D. A., and JACOBSON, M. (1979). Patterns of cell proliferation in the retina of the clawed frog during development. J. Comp. Neurol. $183,603-614$.

BlaXteR, J. H. S., and JoNes, M. P. (1967). The development of the retina and retinomotor responses in the herring (Clupea harengus). J. Mar. Biol. Assoc. LIK 47,677-697.

Blaxter, J. H. S., and Staines, M. (1970). Pure-cone retinae and retinomotor responses in larval teleosts. J. Mar. Biol. Assoc. UK 50, $449-460$.

Boulder Committee. (1970). Embryonic vertebrate CNS: Revised terminology. Anat. Rec. 166, 257-262.

BranacheK, T., and BreMiller, R. (1984). The development of photoreceptors in the zebrafish, Brachydanio rerio. I. Structure. J. Comp. Neurol. 224, 107-115.

Brown, M. E. (1957). In "The Physiology of Fishes" (M. E. Brown, Ed.), Vol. I, pp. 361-400. Academic Press, New York. 
Carter-Dawson, L. D., and LaVAil, M. M. (1979). Rods and cones in the mouse retina. II. Autoradiographic analysis of cell generation using tritiated thymidine. J. Comp. Neurol. 188, 263-272.

Davis, T. L., Spencer, R. F., and Sterling, P. (1979). Preparing autoradiograms of serial sections for electron microscopy. $J$. Neurosci. Methods 1, 179-183.

EASTER, S. S. (1983). Postnatal neurogenesis and changing connections. Trends Neurasci. 6, 53-56.

Fujita, S. (1962). Kinetics of cellular proliferation. Exp. Cell Res. 28, $52-60$.

GlUCKSMann, A. (1940). Development and differentiation of the tadpole eye. Brit. J. Ophthalmol. 24, 153-178.

Heathcote, R. D., and SARG'N'I, P. B. (1984). The genesis and differentiation of neurons in a frog parasympathetic ganglion. Dev. Biol. 105, 102-114.

HINDS, J. W., and Hinds, P. L. (1974). Early ganglion cell differentiation in the mouse retina: An electron microscopic analysis utilizing serial sections. Dev. Biol. 37, 381-416.

JoHNS, P. R. (1977). Growth of the adult goldfish eye. III. Source of the new retinal cells. J. Comp. Neurol. 176, 343-358.

JoHns, P. R. (1981). Growth of fish retinas. Amer. Zool. 21, 447-458.

JoHns, P. R. (1982). The formation of photoreceptors in the growing retinas of larval and adult goldfish. J. Neurosci. 2, 179-198.

JoHns, P. R., and EASTER, S. S. (1977). Growth of the adult goldfish eye. II. Increase in retinal cell number. J. Comp. Neurol. 176, 331342.

JoHNS, P. R., and FERNALD, R. D. (1981). Genesis of rods in teleost fish retina. Nature (London) 293, 141-142.

KaJishima, T. (1960). The normal developmental stages of the goldfish, Carassius auratus. Japan. J. Icthyol. 8, 20-28.

KOCK, J.-H. (1982). Neuronal addition and retinal expansion during growth of the crucian carp eye. J. Comp. Neurol. 209, 264-274.

KOCK, J.-H., and REUTER, R. (1978). Retinal ganglion cells in the crucian carp (C. carassius). I. Size and number of somata in eyes of different size. J. Comp. Neurol. 179, 535-548.

LANGFord, L. A., and CogGeshall, R. E. (1980). The use of potassium ferricyanide in neural fixation. Anat. Rec. 197, 297-303.

LANGFORD, L. A., and COGGESHALL, R. E. (1981). Branching of sensory axons in the peripheral nerve of the rat. J. Comp. Neurol. 203, 745750 .

LOCKET, N. A. (1980). Variation of architecture with size in the multiplebank retina of a deep-sea teleost, Chauliodus sloani. Proc. $R$. Soc. London B. 208, 223-242.

Lyall, A. H. (1957). The growth of the trout retina. Q. J. Mirrosc. Sci. 98, 101-110.

MEYER, R. L. (1978). Evidence from thymidine labeling for continuing growth of retina and tectum in juvenile goldfish. Exp. Neurol. 59, 99-111.

MUtler, H. (1952). Bau und wachstum der Netzhant des Guppy (Lebistes reticulatus). Zool. Jb. 63, 275-324.

MuNK, O., and JøRGENSEN, J. M. (1983). Mitoses in the retina of two deep-sea teleosts. Vidensk. Meddr. Dansk. Naturh. Foren. 144, 7581.

NeGISHI, K., TERANISHI, T., and KATO, S. (1985). Retinal growth in carp of the same age: Density and number of dopamine neurons. Brain Res. 350, 125-131.

RAKIC, P. (1971). Neuron-glia relationship during granule cell migra- tion in developing cerebellar cortex. A Golgi and electron microscopic study in Macacus rhesus. J. Comp. Neurol. 141, 283-312.

RAKIC, P. (1972). Mode of cell migration to the superficial layers of fetal monkey cortex. J. Comp. Neurol. 145, 61-84.

Ramón y CaJAL, S. (1893). "The Structure of the Retina" (S. A. Thorpe and M. Glickstein, Trans.), Thomas, Springfield, IL (1972).

RAMón y CAJAL, S. (1909-1911). "Histologie du Système Nerveaux de l'Homme et des Vertébrés," (L. Azoulay, Trans.). Vol. I. Reprinted by Institute Ramón y Cajal del C.S.I.C., Madrid (1952-1955).

RAYMOND, P. A. (1985a). The unique origin of rod photoreceptors in the teleost retina. Trends Neurosci. 8, 12-17.

RAYMOND, P. A. (1985b). Cytodifferentiation of photoreceptors in larval goldfish: Delayed maturation of rods. J. Comp. Neurol. 236, 90-105.

RAYMOND, P. A. (1986). Movement of retinal terminals in goldfish tectum predicted by analysis of neuronal proliferation. J. Neurosci. 6, 2479-2488.

RAYMOND, P. A., and EAster, S. S. (1983). Postembryonic growth of the optic tectum in goldfish. I. Location of germinal cells and numbers of neurons produced. J. Neurosci. 3, 1077-1091.

RAYMOND, P. A., and Rivlin, P. K. (1981). Three-dimensional reconstruction from serial, electron microscopic autoradiographs of dividing rod precursors in the goldfish retina. In "Proceedings 42nd Annual Meeting EMSA" (G. W. Bailey, Ed.), pp. 724-725. San Francisco Press.

RAYMOND, P. A., and RIVLIN, P. K. (1985). Ontogeny of rods in goldfish retina: Migration of precursors along Müller fibers. Invest. Ophthalmol. Visual Sci. 26, (Suppl.), 336.

Rogers, A. W. (1979). "Techniques of Autoradiography," 3rd ed. Elsevier/North-Holland, New York.

SALPETER, M. M., and BACHMANN, L. (1964). Autoradiography with the electron microscope. A procedure for improving resolution, sensitivity and contrast. $I$. Cell Biol. 22, 469-477.

SANDY, J. M., and BLAXTER, J. H. S. (1980). A study of retinal development in larval herring and sole. J. Mar. Biol. Assoc. UK 60, 59-71.

SAUER, F. C. (1936). The interkinetic nuclear migration of embryonic epithelial nuclei. J. Morphol 60, 1-11.

SCHOLES, J. H. (1976). Neuronal connections and cellular arrangement in the fish retina. In "Neural Principles in Vision" (F. Zettler and R. Weiler, Eds), pp. 63-93. Springer-Verlag, New York.

SEYmour, R. M., and BERRY, M. (1975). Scanning and transmission electron microscopic studies of interkinetic nuclear migration in the cerebral vesicles of the rat. J. Comp. Neurol. 160, 105-126.

SIDMAN, R. L., and RAKIC, P. (1973). Neuronal migration with special reference to developing human brain: A review. Brain Res. 62, 1-35.

STRAZNICKY, K., and GAZE, R. M. (1971). The growth of the retina in Xenopus laevis: $\Lambda$ n autoradiographic study. J. Embryol Exp. Morphol. 26, 67-79.

Vilter, V. (1947). Architectonique de la rétine nerveuse de la carpe et theorie de la dualité des mechanisms de la photoperception visuelle. C. R. Soc. Biol. Paris 141, 348-350.

VILTER, V., and LEwin, L. (1954). Existence et répartition des mitoses dans la rétine d'un poisson abyssal, Bathylagus benedicti. C. $R$. Soc. Biol. (Paris) 148, 1771-1775.

Wolburg, H., and KuRz-Isler, G. (1977). Microtubules and microtubule-like structures in the retina of the rainbow trout. Cell Tissue Res. 177, 127-140. 